\title{
A influência do governo federal sobre cidades na Amazônia: os casos de Marabá e Medicilândia
}

Ana Cláudia Duarte Cardoso - Doutora em Arquitetura, Phd - Oxford Brookes University. Professora Universidade Federal do Pará.

José Júlio Ferreira Lima - Doutor em Arquitetura, Phd - Oxford Brookes University. Professor da Universidade Federal do Pará.

\section{Resumo}

Apesar da existência de diversos trabalhos acadêmicos sobre o processo de transformação socioeconômica das cidades da região, pouco dessa literatura ofereceu interpretações que considerassem a configuração espacial como análise. Este artigo procura mostrar a origem e a evolução de uma cidade como Marabá que serve de contraponto à concepção do "urbanismo rural" que gestou as cidades de "beira de estrada", caso de Medicilândia e dos núcleos que hoje compõem a cidade de Marabá. Por último, foi lançado um olhar sobre a explícita especulação imobiliária em curso na Cidade Nova, terceiro e mais recente arranjo urbanístico instalado em Marabá.

\begin{abstract}
Despite the existence of several academic works on the process of socio-economical transformation of towns in the south of Pará, little of this literature offered interpretations which considered the spatial configuration as analysis. This article tries to show the origin and evolution of a town like Marabá, which works as counterpoint to the conception of "rural urbanism" that managed the towns "along the roads", like Medicilândia and nucleus that constitute the town of Marabá. Finally, one notices the explicit real estate speculation operating in Cidade Nova, the third and more recent urban setting installed in Marabá.
\end{abstract}

\section{Palavras-chave}

Cidades, Marabá, Medicilância, Amazania.

\section{Keywords}

Cities, Maraba, Medicilândia, Amazon. 


\section{INTRODUÇÃO}

A atuação do governo federal na Amazônia durante as décadas de 60 e 70 do século XX ocorreu majoritariamente no âmbito regional, por meio da adoção de um modelo de desenvolvimento econômico baseado na exploração dos recursos naturais e da potencialidade energética da região (MAGALHÃES; BRITTO; CASTRO, 1996). A dispersão da população pelo território contribuiu para a difusão da idéia de que a região era um vazio demográfico - as cidades eram escassas e pequenas - que deveria ser povoado e integrado ao país. Com a implantação dos grandes projetos (como a abertura da Transamazônica, o início da exploração mineral em Carajás, a construção da Usina Hidrelétrica de Tucuruí), foram abertas frentes de trabalho que atraíram milhares de trabalhadores e revelaram a grande disponibilidade de terras na região. As estradas promoveram uma mudança no padrão de ocupação do território, viabilizando o surgimento de cidades ao longo delas (como a cidade de Medicilândia), completamente desvinculadas da acessibilidade fluvial observada nas cidades tradicionais. Nos casos em que os padrões de acessibilidade rodoviária e fluvial se superpuseram (como em Marabá), as funções comerciais e administrativas foram fortalecidas a ponto de compensar desvantagens, como as enchentes recorrentes, e chamar a atenção do governo federal para a necessidade de intervenção na escala urbana. Neste artigo, utilizam-se os casos de Medicilândia e Marabá para ilustrar dois processos distintos, relacionados à presença do governo federal na região.

O primeiro caso ilustra o modo como a rodovia Transamazônica constituiuse em vetor de instalação de cidades na região amazônica, do ponto de vista tanto econômico quanto espacial. Os tipos de cidades observados ao longo das margens da estrada guardam relações com o projeto de desenvolvimento pensado para a região e sua concepção de ocupação do espaço geográfico, tomado a partir da escala regional; contudo, quando as formulações urbanísticas vinculadas ao processo são consideradas, verifica-se que muito pouco foi realizado, restando apenas uma vaga lembrança do que foi proposto nos documentos federais.

Por outro lado, as transformações em Marabá sintetizam diversos tipos urbanos criados por uma sociedade em processo de urbanização. As formas tradicionais de vida urbana na cidade mantêm-se paralelamente à construção de várias cidades em uma só. Além da competição do capital pelo espaço, em Marabá os agentes sociais organizam-se e reorganizam-se em rearranjos econômicos e espaciais de fundamental importância para que se entenda o que significa e para que serve a cidade na Amazônia neste início de século. 
Apesar da existência de diversos trabalhos acadêmicos sobre o processo de transformação socioeconômica das cidades da região, pouco dessa literatura ofereceu interpretações que considerassem a configuração espacial como dimensão de análise (BECKER; NASCIMENTO; COUTO, 1996). Com o intuito de defender uma visão que ligue o espaço aos processos socioeconômicos ocorridos na região, procura-se associar a forma da "cidade beira da estrada", verificada em Medicilândia e em tantas outras, aos esquemas, anteprojetos teóricos e planos ensaiados para orientar a configuração dos núcleos urbanos que serviriam de apoio para o urbanismo rural, planejado como estratégia de colonização para a região - idéia proposta pelo arquiteto e urbanista José Geraldo da Cunha Camargo para o Ministério da Agricultura (CAMARGO, 1973). Com este estudo, esperase contribuir para a discussão sobre a experiência prática de implantação desse projeto e para a compreensão da condição atual de Medicilândia a partir de sua origem e de sua evolução.

A compreensão da origem e da evolução de uma cidade tradicional como Marabá serve de contraponto à concepção do "urbanismo rural" que gestou as cidades de "beira de estrada", caso de Medicilândia e dos núcleos que hoje compõem a cidade de Marabá. Caracterizando-se cada um dos núcleos urbanos que se acomodaram no território que corresponde à cidade como um todo. A análise é iniciada pela Marabá pioneira, núcleo consolidado, tomado como manifestação da recorrência do clientelismo na região, exemplificado pela relação de dependência entre os atores que interagem naquele espaço por ocasião das constantes cheias dos rios que banham a cidade - rios Itacaiúnas e Tocantins - e pelas relações travadas por ocasião das novas intervenções infra-estruturais. A seguir, são abordadas as dificuldades de implementação de um projeto-desenho no Núcleo Nova Marabá em meio ao autoritarismo da década de 70 no país, destacando-se essa experiência como uma das raras intervenções do governo federal no espaço intra-urbano naquela época. Por último, foi lançado um olhar sobre a explícita especulação imobiliária em curso na Cidade Nova, terceiro e mais recente arranjo urbanístico instalado em Marabá, como ilustração dos processos de ocupação típicos do período posterior à retirada do governo federal daquele contexto.

\section{A CIDADE DE MEDICILÂNDIA}

\subsection{A concepção teórica}

A iniciativa do governo brasileiro de implantar, durante os anos 70, o urbanismo rural ao longo da rodovia Transamazônica, segundo proposta de Camargo (1973), para toda a extensão da rodovia, desde Estreito (MA) até Itaituba 
(PA), foi no mínimo ousada. A proposta baseava-se na experiência acumulada pelo Instituto Nacional de Colonização e Reforma Agrária (INCRA) e por setores correlatos do Ministério da Agricultura, desde a experiência dos Núcleos Coloniais Oficiais, implantados em 1956. O urbanismo rural ou planejamento urbano-rural (ver Figura 1) consistia em uma estratégia de colonização da Amazônia, baseada no conhecimento técnico da área (pedologia, topografia, cobertura vegetal, etc.), no planejamento físico-espacial, sociocultural e econômico, visando ao "desenvolvimento integrado do meio rural" (CAMARGO, 1973, p. 4).

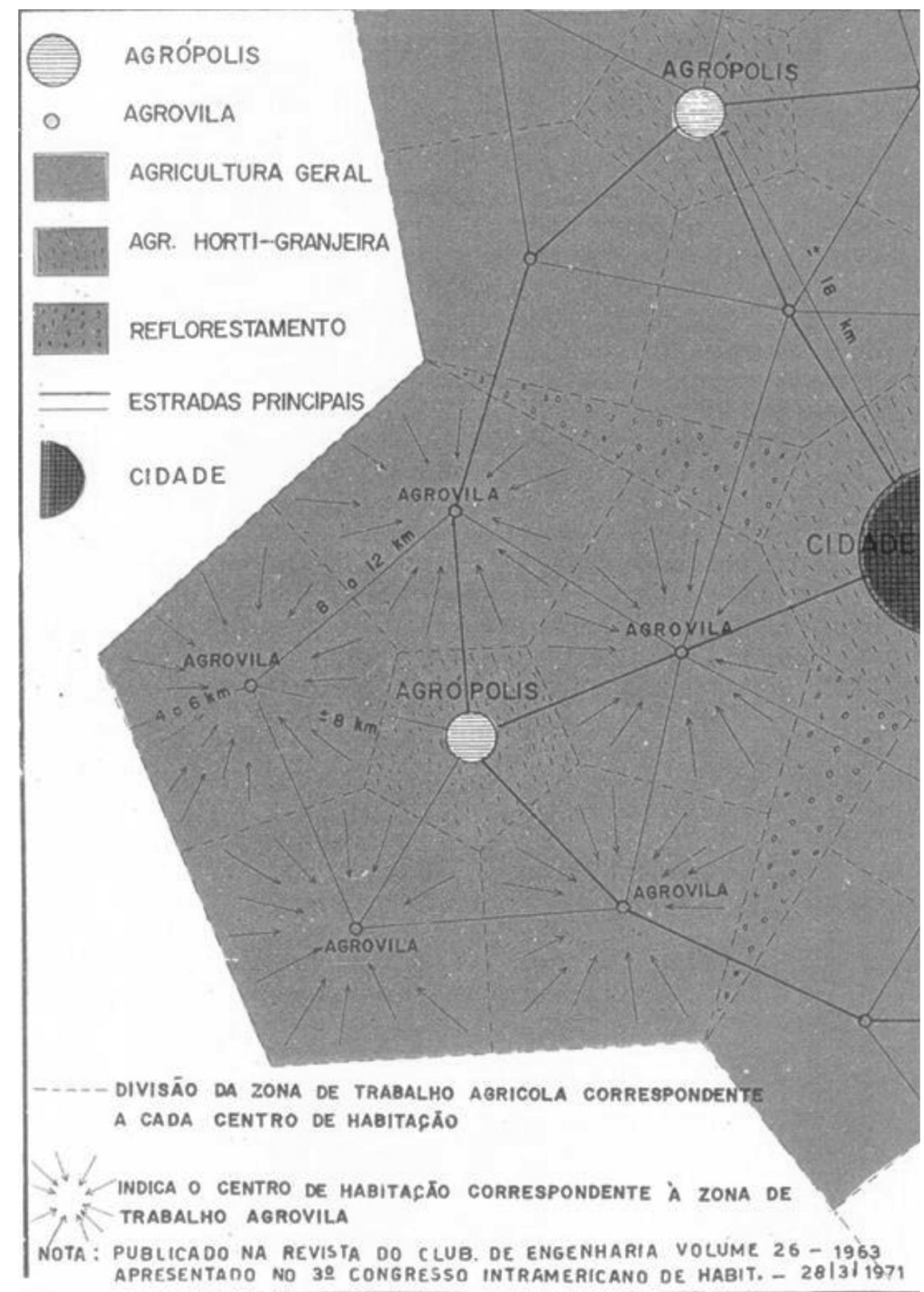

Figura 1: Zoneamento esquemático do planejamento urbano-rural. Fonte: Camargo, 1973. 
Tal estratégia pressupunha uma forte presença do Estado, com a atuação intensiva, nas diversas etapas do processo, de equipes de profissionais formadas por urbanistas, economistas, agrônomos, sociólogos, engenheiros civis, arquitetos, engenheiros sanitaristas, médicos, advogados, assistentes sociais, educadores, psicólogos, etc. As etapas de prospecção e planejamento envolveriam parte das equipes, a etapa de implantação do projeto, outra parte, assim como o acompanhamento do assentamento dos primeiros colonos. Previa-se a "doutrinação" dos novos moradores com o objetivo de garantir o controle social das novas comunidades, a assistência técnica para orientar os colonos a usar a terra que então recebiam e a hierarquização da ocupação humana da seguinte forma: a) lotes agrícolas, dependendo das condições de topografia, clima, solo e grau de tecnologia a ser adotado; b) agrovila ou comunidade rural, para abrigar até 1500 habitantes; c) agrópolis ou bairro rural, para abrigar de 1500 a 3000 habitantes em lotes de 125 hectares; d) rurópolis ou centro urbano - dotado de equipamentos urbanos, zona industrial, lotes urbanos e lotes para rurícolas -, que abrigaria 20.000 habitantes e funcionaria como sede de uma ampla comunidade rural.

Observe-se que a concepção de Camargo (1973) procurava ser flexível, de modo a garantir que no decorrer do processo uma agrovila pudesse transformar-se em uma agrópolis, passando sucessivamente para as demais categorias. A concepção previa o adensamento gradual da ocupação rural, na medida em que a tecnologia assim o permitisse (por mecanização do campo, especialização da mão-de-obra, etc.), de tal modo que o acesso à infra-estrutura, a equipamentos comunitários e a alternativas de lazer fosse garantido a todos. A determinação de distâncias mínimas e a definição de localização de equipamentos comunitários dependeriam da tecnologia de transporte disponível e estariam baseadas, não em distâncias propriamente ditas, mas no tempo gasto para o deslocamento. As sugestões apresentadas em esquemas espaciais demonstravam uma clara preocupação com a setorização de usos, a modulação do assentamento e o afastamento do uso habitacional da rodovia principal (Figura 2). 


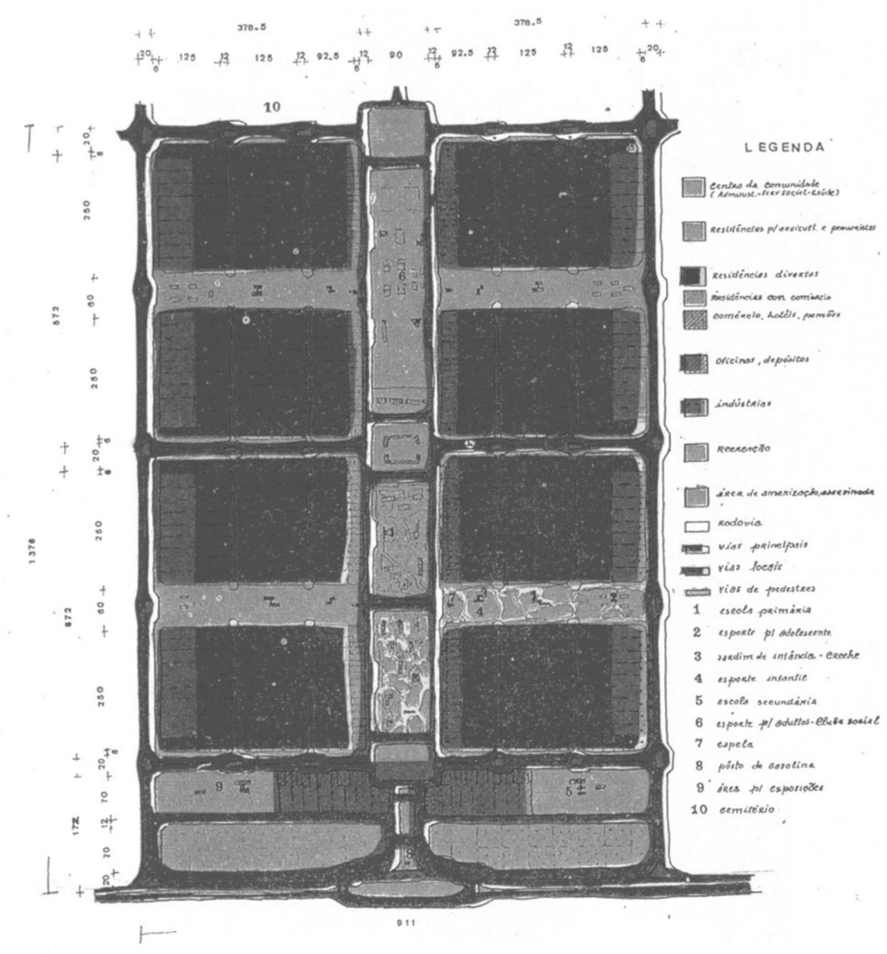

Figura 2: Esquema de localização e configuração dos assentamentos a serem localizados ao longo da Rodovia Transamazônica.

Fonte: Camargo, 1973, p. 18.

O lote de moradia era o módulo básico na escala urbana, e suas dimensões reconheciam a necessidade de práticas de subsistência perto da habitação (como prática de lavoura branca, horticultura, criação de aves), prevendo-se área de 500 a $3.000 \mathrm{~m}^{2}$. Na escala regional, o módulo era um quadrilátero de 42,8 x 21,4 km, com área de 183.184 ha, cortado em dois retângulos pela rodovia. A agrópolis ficaria situada em uma das margens, aproximadamente no centro do módulo, com área inicial de 225 ha mais 405 ha reservados para crescimento futuro; a agrovila contaria com 50 ha mais os 75 ha dos lotes rurais, com um raio de influência sobre 48 lotes rurais de 100 ha. Os limites do módulo seriam definidos por estradas vicinais, que dariam acesso a agrovilas, que deveriam ter metade de sua área de influência em um módulo de colonização e metade no módulo vizinho. Os quatro vértices do módulo seriam reservados para futuras agrópolis a serem implantadas por ocasião da ocupação do módulo de colonização adjacente. Reservas florestais eram previstas nos interstícios dos assentamentos, com acessos viabilizados a partir das agrovilas. 


\subsection{A experiência prática}

De acordo com o esquema de colonização da Transamazônica, Medicilândia seria a agrópolis número 11, localizada após a agrópolis de Brasil Novo, no sentido de Altamira para Itaituba. O texto de Camargo menciona que, em 1973, seria iniciada a construção de uma agrovila a $90 \mathrm{~km}$ de Altamira, que mais tarde viria a ser chamada Medicilândia, onde já estava sendo construída uma usina de açúcar; ao longo daquele trecho estavam em curso projetos para mais três agrovilas da Transamazônica. Note-se que Altamira, Marabá e Itaituba eram consideradas rurópolis pelo esquema, em função do apoio logístico que ofereciam ao projeto de colonização como um todo.

Prospecções revelaram que o solo daquela área era rico em terra roxa; em decorrência disso, o traçado da rodovia Transamazônica foi definido de modo a aproveitar ao máximo a ocorrência desse solo, com a implantação dos chamados travessões (vicinais previstas no projeto citado), do então Projeto Abraham Lincoln (Projeto PACAL), ao qual a usina de açúcar estava vinculada, e posteriormente da agrovila de Medicilândia sobre a terra roxa. A implantação espacial do Projeto PACAL, em 1974, foi tecnicamente correta, adaptada às condições do relevo. A infra-estrutura do projeto era adequada (dispunha da maior agência do Banco do Brasil na região) e os lotes rurais estavam comprometidos com a produção de cana-de-açúcar em sua área de influência, mas o projeto não resistiu aos problemas administrativos e às limitações produtivas, fechando em 2000, após atravessar uma crise em 1983 e outra em 1985.

Como a implantação do projeto não foi completa, a agrovila não se efetivou paralelamente à implantação da usina de açúcar, e, por pressão dos colonos, ainda em 1973, houve a ocupação de um lote rural, posteriormente cedido pelo INCRA, localizado a $2 \mathrm{~km}$ da usina de açúcar, na margem sul da rodovia Transamazônica, para a criação da agrovila de Medicilândia. Com o declínio dos investimentos do governo federal na região, não houve nenhum projeto elaborado segundo as recomendações de Camargo (1973), nem se deu atenção às limitações impostas à implantação da agrovila pela ondulação do sítio; tampouco questões fundiárias foram encaminhadas como necessário, nem existiu o apoio dos profissionais para garantir assistência técnica ou acompanhamento social à população.

Da concepção espacial (e teórica) de Camargo (1973) para as agrovilas da Transamazônica, restaram apenas influências, como a definição da localização e a determinação do INCRA para que a ocupação ocorresse apenas em um lado da rodovia (Figura 3). Ainda assim, a modulação defendida não foi estabelecida, e os loteamentos - que correspondem aos bairros atuais - foram sendo criados progressivamente, à medida que aumentava a população. Não houve hierarquização 
das ruas nem zoneamento de usos, e o centro administrativo e comercial da futura cidade foi estabelecido às margens da rodovia, sem a faixa de amortecimento sugerida na concepção teórica original.

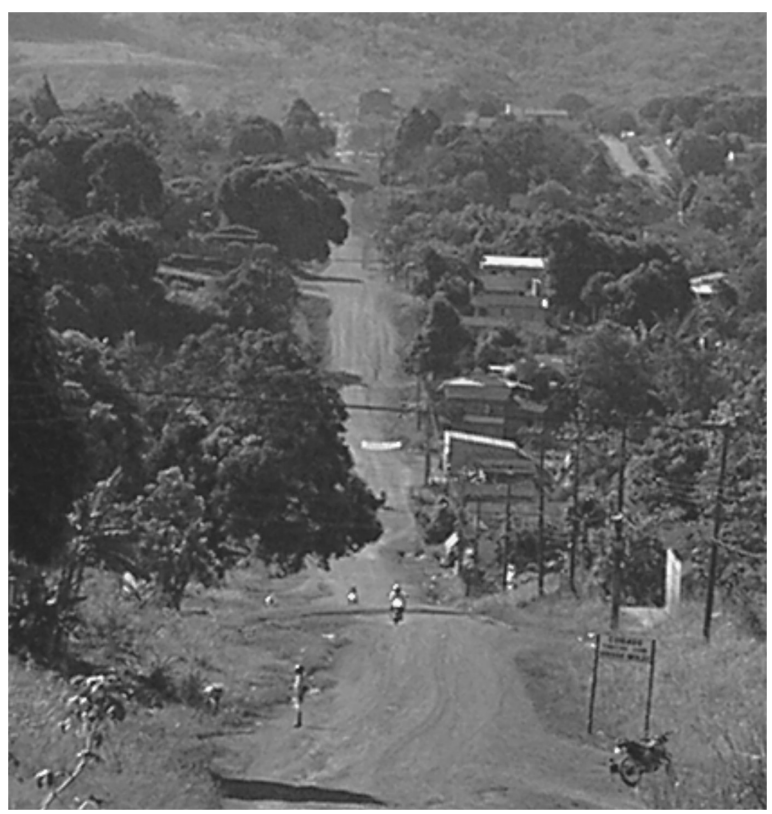

Figura 3: Via longitudinal da cidade, vista da Transamazônica. Foto: FVPP; UFPA, 2005.

No âmbito político, o desbravamento da região resultou na criação de novos municípios alinhados ao longo da rodovia. Com a criação do município de Medicilândia em 1988, a agrovila de ocupação espontânea do km 90 transformouse em sede de município.

A partir de 1989, novos lotes foram acrescidos ao lote original cedido pelo INCRA - lote Bento (1989/1990), lote Dezinho e Saturnino (1990/1991) e lote Carvalho (1999/2000). Assim, a cidade expandiu-se por meio de loteamentos criados pelos fazendeiros donos das terras, sem nenhum controle por parte do poder público. A associação de tal processo de expansão à centralidade assumida pela rodovia em relação à cidade subverteu a proposta de contenção da cidade em uma das margens da rodovia. Com efeito, a rodovia passou a ser a avenida principal da cidade, definindo a expansão urbana ao longo do seu eixo.

Tal processo confirma o que se registra na literatura sobre a história da cidade e do urbanismo: as pequenas aglomerações tendem a assumir uma conformação linear, transformando o principal eixo de acesso em foco do assentamento - local de concentração do comércio, da igreja e dos equipamentos 
públicos (MCCLUSKEY, 1985; MORRIS, 1994). Tal arranjo é muito comum em cidades européias, especialmente nas de origem medieval, que, embora de formação espontânea, foram organizadas a partir da tradição (prática das artes urbanas) e da coesão social.

O traçado implantado em Medicilândia (Figura 4) foi a quadrícula tradicional, apesar das limitações da topografia e da presença de cursos d'água. Foi garantida a continuidade da malha em direção ao cemitério, cuja rua conduz a duas vicinais de acesso a lotes rurais. Quando o sistema de ruas da cidade é analisado independentemente da rodovia, observa-se a forte centralidade desse eixo longitudinal e um bom potencial de acesso na maior parte da cidade vinculada à rodovia - setor oeste, que sofre progressivo abandono devido a problemas fundiários (até o presente, ainda não foi concluído o processo de transferência de titulação da terra doada pelo INCRA), à carência de saneamento e a obstáculos topográficos. Na prática, a centralidade da rua mais longa da cidade corresponde à concentração de atividades não residenciais de caráter local, visto que a centralidade da rodovia é muito mais forte, atraindo para as suas margens os usos comerciais mais especializados, as feiras de produtores, os serviços (hotéis, bancos, restaurantes) voltados para o atendimento dos viajantes e da comunidade do entorno da cidade. Tal concorrência é bastante desfavorável para a consolidação de centralidades internas, e atualmente se observa o abandono de lotes em bairros periféricos (mais ao sul) da cidade e a retomada de ruas já abertas pela vegetação.

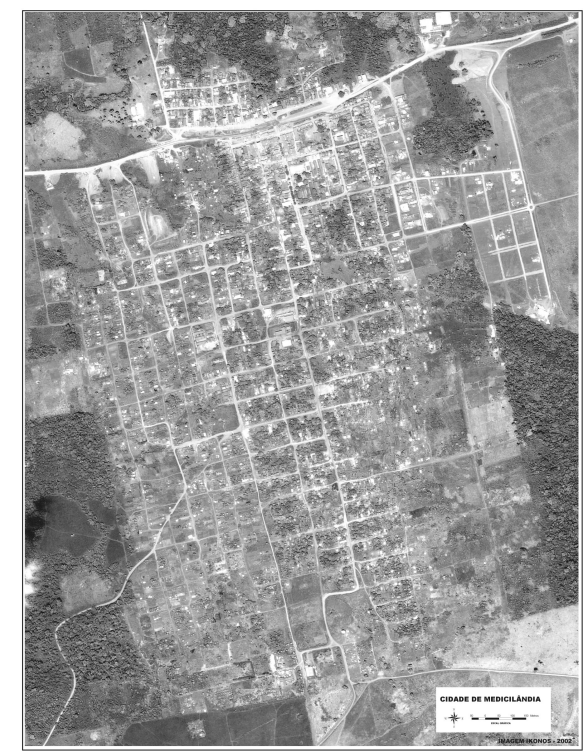

Figura 4: Imagem de satélite da sede (cidade) de Medicilândia. Fonte: FVPP. UFPA, 2006 a partir de imagem do satélite Quick Bird (2005). 
É digno de nota que, mesmo no pequeno universo da cidade de Medicilândia, existam periferias bem localizadas, constituídas pelas áreas sujeitas a alagamento, próximas à rodovia (direção oeste), que abrigavam usos incômodos, como o matadouro (cujo funcionamento era completamente irregular), e que foram ocupadas pela população excluída, por meio de palafitas, no bairro Cacoal. No extremo oposto (direção leste), estão surgindo os condomínios de habitantes com renda superior, nos bairros Carvalho e Floresta, onde não existiria impedimento à regularização fundiária e ao acesso a financiamentos para a construção de habitação.

O crescimento da cidade na direção norte, a partir da margem oposta da rodovia é recente e limitado pela topografia, mas foi fundamental para a transformação do status da rodovia dentro da cidade. Atualmente uma das maiores demandas da população é a construção da frente da cidade, nos moldes do que se construiu em cidades próximas, como Uruará, posteriores ao projeto de colonização. Ainda que existam bairros que não sejam servidos por água encanada, a população clama pela construção de um centro simbólico para a cidade. À medida que aumenta a distância da rodovia, a cidade torna-se mais difusa ou mostra com mais clareza sua condição de cidade agrária (WEBER, 1921), pela intensa prática agrícola dos habitantes no seu lote de moradia e pela progressiva absorção das quadras pelo espaço rural.

Nesse sentido, o preço da terra situada à margem da rodovia é equiparado ao preço praticado em cidades maiores, como Altamira, caindo vertiginosamente à medida que o lote se afasta da rodovia, o que reflete os gradientes de urbanidade experimentados. A população carece de praças e de espaços de convívio, visto que a precariedade das ruas não permite o uso do espaço público como espaço de socialização (Figura 5 e Figura 6). O lazer é bastante restrito, e são comuns os casos de emergência traumatológica decorrentes de acidentes relacionados à prática de esportes radicais como o motocross (que conta com sítios muito favoráveis para sua prática). Por outro lado, o lazer é associado à prostituição feminina, característica da rua do Sopapo (ruas Tabajara e Henrique Dantas).
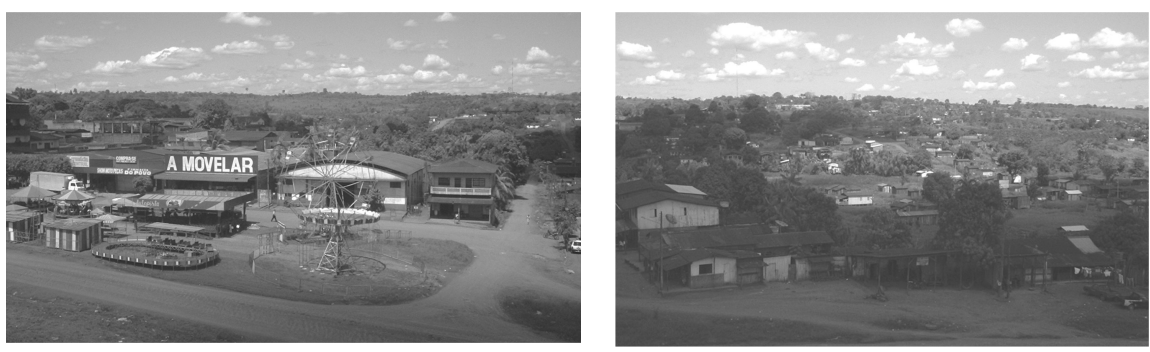

Figura 5: Área central de Medicilândia vista da Transamazônica. Fotos: FVPP; UFPA, 2005. 


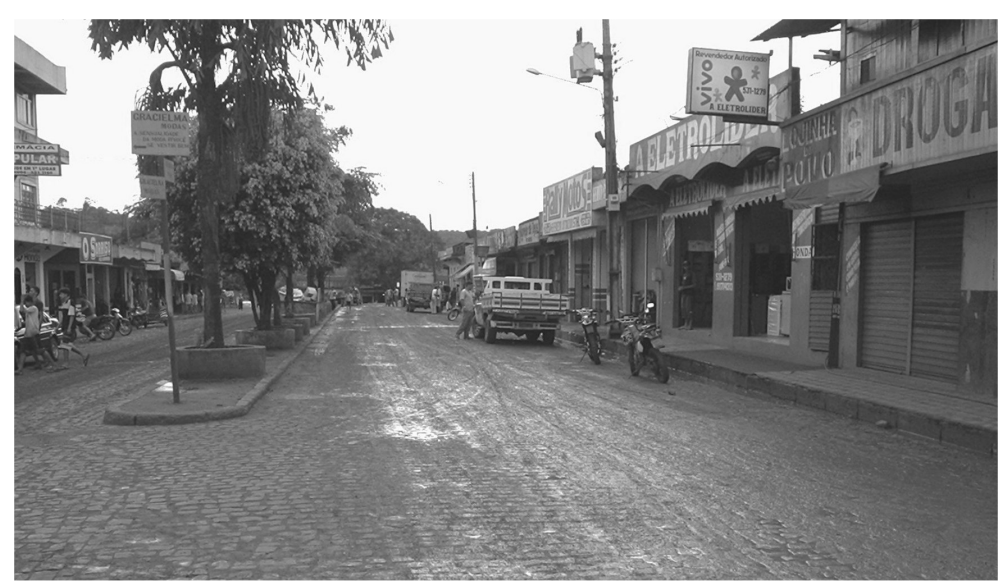

Figura 6: Aspecto da principal avenida da cidade de Medicilândia, única pavimentada.

Foto: FVPP; UFPA, 2005.

Os benefícios da vida urbana ainda são muito limitados, principalmente no que diz respeito ao acesso à infra-estrutura. A origem diversa da população retarda a construção de uma identidade social, e ainda são fortes os conflitos transferidos do campo para a cidade. Atualmente o morador pobre da cidade é o expropriado do campo, que já não dispõe de um lote agrícola para garantir o seu sustento, enquanto a melhor condição socioeconômica é associada à produção rural ou à exploração de um lote agrícola.

\section{A CIDADE DE MARABÁ}

\subsection{Origens da cidade de Marabá}

O núcleo original da cidade de Marabá foi constituído ainda no século XIX, como ponto de apoio à exploração do caucho (uma espécie de gomífera) por comerciantes oriundos da cidade de Baião e do Estado do Maranhão reivindicaram a emancipação da área do município de Baião por não se considerarem assistidos. O movimento pela emancipação fortaleceu-se em 1907, quando os habitantes da vila manifestaram ao governo de Goiás a intenção de se vincularem àquele Estado; como reação ao fato, o governo do Pará criou o município de São João do Araguaia, do qual a região de Marabá tornou-se distrito.

A vila caracterizava-se pela forte polarização, atraindo contingentes populacionais e mercadorias de outros estados. Carvalho (apud VELHO, 1972, p. 43) declara: "Desde o Piuahi, todo o Sertão exportou viveres, carne de boi e de porco; toucinho, farinha sêcca e de puba, assucar, rapadura, cachaça, tabaco, doces, queijos, gallinhas". A pujança do comércio foi um importante fator para que a 
luta pela emancipação continuasse e ocorresse a criação desse município em 1913.

Velho (1972, p. 43) descreve o início do assentamento:

Marabá, no seu início, era assim. Muito mais do que no caso do Burgo, sua função primordial era o comércio. Seu aspecto urbano miserável contrastava com a riqueza do esplendor da borracha. No entanto, sua importância crescente fez com que posteriormente, mais afastada da beira do rio, surgissem casas melhores e aos poucos uma verdadeira pequena cidade.

O primeiro povoamento estabeleceu-se na foz do Itacaiúnas, contudo as adversidades impostas pelas características naturais do sítio físico, como as enchentes anuais, provocaram o deslocamento desse povoamento para outras áreas tidas como mais favoráveis. A ocupação consolidou-se posteriormente na foz do Itacaiúnas, quando essa região se revela muito rica em caucho e favorável ao escoamento de sua produção devido à boa acessibilidade fluvial, pelos rios Itacaiúnas e Tocantins (VELHO, 1972). O primeiro intendente eleito tomou posse em 1914, quando foi estabelecida a sede da comarca.

O ano de 1919 foi fatal para a prosperidade econômica da borracha. Começou então o despovoamento do território e o retorno das famílias para o sertão, seu local de origem. Toda a Amazônia atravessou um processo de involução econômica, cuja recuperação só viria lentamente por volta de 1940. Após o declínio da exploração do caucho, com a crise da borracha, foi retomada a exploração da castanha, cujo ciclo se inicia por volta de 1920. A exploração da castanha já ocorria anteriormente no Baixo Tocantins, destinada ao consumo de porcos e aves na área de Belém e Cametá. Antes da descoberta dos cauchais da foz de Itacaiúnas, a castanha liderou por muitos anos a economia do município para o consumo de mata. Na nova fase, a exploração da castanha beneficiou-se com toda a infraestrutura agregada durante o ciclo da borracha, reutilizando-a e voltando-se para o mercado externo (VELHO, 1972). Com a prosperidade vivida, Marabá assumiu a posição de centro econômico e administrativo de uma vasta região da "fronteira agrícola Amazônica", funcionando até os anos 60 como centro comercial e de serviços (UFPA; PREFEITURA DE MARABÁ, 2006).

A exploração da castanha era muito semelhante à da borracha. Os castanhais eram livres, e os comerciantes controlavam os meios de produção da sua coleta, por meio do sistema de aviamento; nesse sistema, os homens empenhados em catar castanhas eram aviados pelos comerciantes, ou seja, recebiam alimento, abrigo, condução, etc., como pagamento pelo trabalho. Na contabilidade do aviador, raramente havia saldo para o trabalhador receber em espécie, o que acarretava a 
perpetuação do vínculo em razão das dívidas acumuladas. E, assim como ocorria no período da borracha, os comerciantes de Marabá que financiavam os castanheiros eram financiados e abastecidos pelos comerciantes e exportadores de Belém. Tal sistema manteve-se durante toda década de 20 (VELHO, 1972).

Outro ciclo econômico que se superpôs ao da castanha foi o dos garimpos. Iniciado com a exploração de diamantes e gemas (ametistas, turmalinas, topázios) e minerais não metálicos (seixo, areia, argila, quartzo), culminou na exploração de metais, como o ouro da Serra Pelada, o ferro de Carajás e a expectativa de exploração de cobre da mina de Salobo. A riqueza mineral da região foi confirmada por relatórios técnicos de subsidiárias da, então estatal, Companhia Vale do Rio Doce, ainda durante a década de 70. Ao longo da trajetória da exploração mineral, observa-se a perpetuação da cultura local de exploração social e ambiental, com forte impacto sobre os fluxos migratórios e as condições de vida na cidade e nos aglomerados da região (UFPA; PREFEITURA DE MARABÁ, 2006).

Por outra via, a tradição pecuarista nunca deixou de estar presente na economia local. Esteve associada ao ciclo da castanha, visto que nos próprios castanhais criavam-se pequenos pastos artificiais para os jumentos. $\mathrm{O}$ gado bovino destinava-se então ao consumo próprio do castanhal (VELHO, 1972). Havia uma relação de complementaridade entre a castanha e a pecuária, na medida em que uma atividade - a pecuária - não substituía a outra - a castanha. A princípio, os empréstimos abertos para a pecuária eram considerados insuficientes e caros, o que criou uma prática de desvio dos empréstimos destinados à castanha para a pecuária. Quando, em 1954, a pecuária recebeu incentivos fiscais por meio da Lei n. ${ }^{\circ}$ 913, acelerou-se o processo de concentração da terra ligada à produção de castanha e à pecuária. Tal fato, associado à decadência do comércio de Marabá (diminuição da capacidade polarizadora da cidade), desencadeou uma grande expropriação de produtores, reduzindo à metade o número de donos de castanhais, em benefício da pecuária. Com o advento do crédito bancário e a abertura da rodovia BelémBrasília, o sistema de aviamento perdeu o sentido; os donos de castanhais ganharam autonomia em relação aos comerciantes de Belém e passaram a fazer compras em outros centros (fora de Marabá) (VELHO, 1972). Enfim, com o declínio do extrativismo, a elite local transferiu seus investimentos para a pecuária.

À trajetória econômica correspondeu à evolução da organização do território. Em 1935, o município encontrava-se subdividido em cinco distritos - a sede municipal, Itupiranga, Jacundá, Santa Isabel e São João da Ponta. A partir 
de 1947, teve início o processo de desmembramento, que culminou na atual organização do território da região. Parte do território foi desmembrado para a criação do município de Itupiranga; em 1961 foi a vez de São João do Araguaia e, em 1988, de Curionópolis e de Parauapebas. No início dos anos 80, o município possuía uma área de $373.373 \mathrm{~km}^{2}$; após os desmembramentos, sua área passou a ser de pouco mais de $15.000 \mathrm{~km}^{2}$. Os municípios desmembrados deram origem a outros, principalmente no final da década de 80 e em meados da década de 90 , em geral em decorrência da dinâmica de exploração mineral estabelecida na região.

Por outro lado, a intensa dinâmica econômica da área rural permitiu a formação de uma elite urbana na cidade de Marabá, constituída pelos detentores dos meios de produção na região (como os donos de terras e os líderes da prática de aviamento, empresários da navegação e comerciantes), o que, por sua vez, viabilizou o surgimento de uma burguesia urbana composta de funcionários públicos e trabalhadores, sem vínculo com o trabalho no campo e as transformações ocorridas nos limites políticos do município (TOURINHO, 1991). As relações entre campo e cidade enfraqueceram-se à medida que as áreas rurais mais dinâmicas emanciparamse para constituir novos municípios, restando no município de Marabá uma população rural desarticulada e desprovida de condições de produção, dispersa em assentamentos do INCRA, fazendas, garimpos e algumas vilas.

Se, por um lado, a localização da cidade sempre favoreceu o extrativismo e a atividade comercial, por outro lado, submeteu-a à vulnerabilidade das enchentes, acarretando a necessidade de remanejamento da população por ocasião das inundações regulares dos bairros populares da Velha Marabá (também chamada Marabá Pioneira) (Figura 7). Esse desafio histórico à Gestão local, favoreceu a segregação sócio-espacial do espaço intra-urbano. As inundações são mais graves quando coincidem as cheias do Itacaiúnas, do Tocantins e do Araguaia e toda a Marabá Pioneira é alagada, e a população é obrigada a se deslocar para abrigos construídos pela Defesa Civil; o assunto já era debatido em 1906, uma a transferência da cidade já era discutida como estratégia de enfrentamento do problema (VELHO, 1972). 


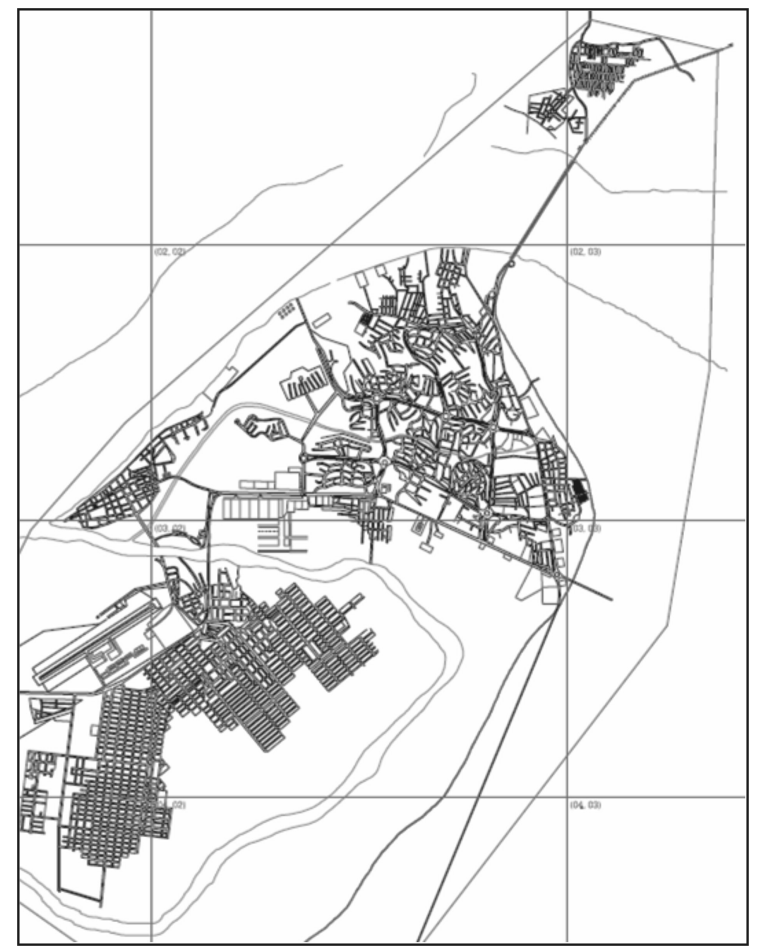

Figura 7 Núcleos que compõem a Cidade de Marabá.

Fonte: levantamento aerofotográfico (COHAB, 1998), atualizado por UFPA PMM (2006) com imagens de satélite.

Por ocasião da grande enchente de 1980, a Superintendência de Desenvolvimento da Amazônia (SUDAM) implantou o núcleo urbano da Nova Marabá. O projeto urbanístico tem características espaciais completamente diferentes da Velha Marabá. Baseado na ocupação extensiva de terras, foi bastante comprometido pela interrupção da atuação da SUDAM na implantação do núcleo, que passou a ser ocupado de modo espontâneo e sem controle urbanístico compatível com as premissas técnicas do projeto. A atuação do governo federal no âmbito da cidade foi rara, visto que a ênfase na época era a instalação de infraestrutura (estradas, fontes de energia) de apoio à exploração dos recursos naturais da região (minérios, madeira), o que ocorria de modo dissociado dos processos de urbanização e expansão urbana. É possível constatar que o problema das enchentes não se restringe apenas ao núcleo Velha Marabá, há porções dos demais núcleos que também sofrem a interferência das águas dos dois rios (Figura 8). 


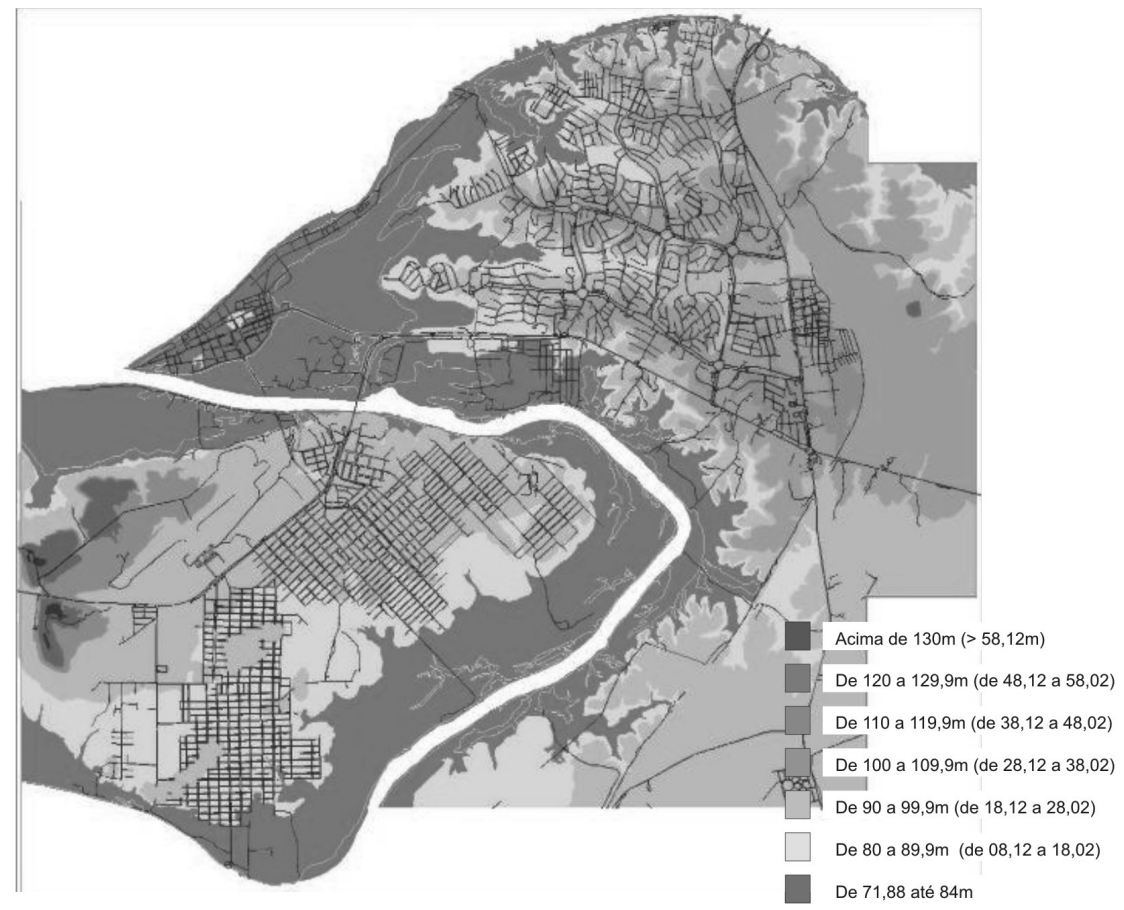

Figura 8: Mapa com a cota do nível máximo da enchente ocorrida na cidade nos anos 80 .

Fonte: ONU, 2006 a partir de base cartográfica (COHAB, 1998).

A construção das estradas modificou consideravelmente as condições de mobilidade e de ocupação do território. No caso da cidade de Marabá, a passagem pela cidade das estradas BR-230 (Transamazônica, principal eixo de articulação estadual no sentido Leste-Oeste) e PA-150 (principal eixo de articulação estadual no sentido Norte-Sul) e da Ferrovia de Carajás (construída para viabilizar o escoamento do minério de ferro extraído da região) potencializou a condição de nó regional, reforçada posteriormente pelo aeroporto, que mantém vôos regulares para Belém e Brasília. A obstrução do rio Tocantins, após a construção da UHE Tucuruí, reduziu a importância do transporte fluvial, ao passo que a ferrovia reforçou os fluxos migratórios do Nordeste para a cidade - já existentes desde sua fundação -, com forte impacto sobre os processos de expansão urbana. A ponte sobre o rio Itacaiúnas ao longo do trajeto da Rodovia Transamazônica fortaleceu a formação do terceiro núcleo urbano da cidade de Marabá, a Cidade Nova, originado por agrovila, que assumiu caráter urbano com a instalação do aeroporto; por outro lado a ponte sobre o rio Tocantins (ao longo da PA-150 e da Ferrovia Carajás) transformou as localidades de São Félix e Morada Nova, localizadas à margem direita do rio Tocantins, em áreas de expansão da cidade (Figura 9). O 
grande perímetro urbano denuncia a concentração de riquezas e os investimentos na cidade, em detrimento da população rural do município. A cidade tornou-se um mosaico de núcleos que, pela gestão deficiente, sofreram ocupação informal, o que gerou problemas ambientais e estendeu o problema das enchentes do núcleo original (a Velha Marabá) para os demais.

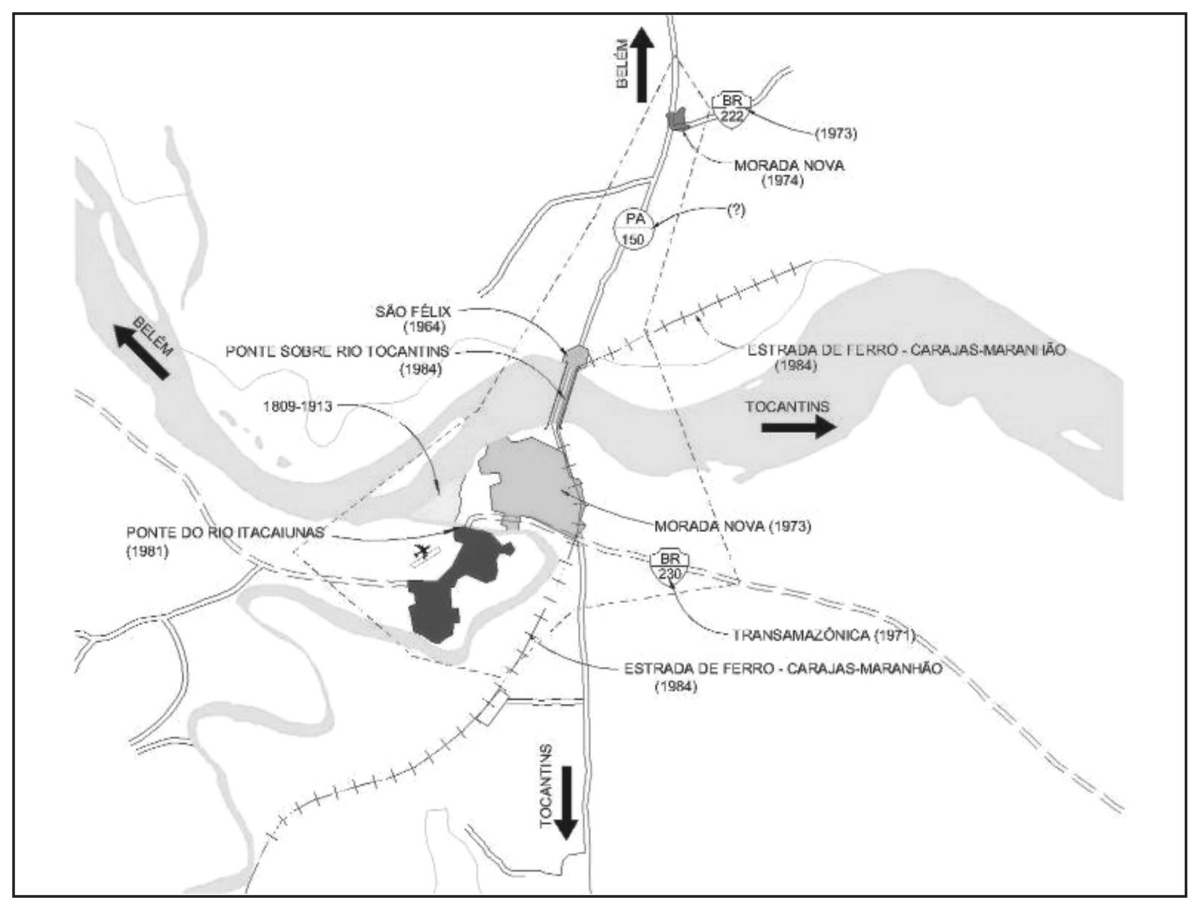

Figura 9: Estruturação espacial no entorno da sede.

Fonte: UFPA, PMM, 2006.

Se antigamente era possível observar as palhoças à beira-rio serem anualmente reconstruídas após as cheias, hoje os moradores adotam novas estratégias para evitar o transtorno da mudança de endereço por causa das enchentes, como a improvisação de pavimentos intermediários em suas casas, onde se abrigam e protegem seus pertences. Nessas circunstâncias, os moradores dependem basicamente do poder público local e de ajudas humanitárias para ter água potável e alimentação.

A inegável condição de pólo da cidade, destacada pela presença de diversos órgãos federais e estaduais, não favorece a gestão do seu espaço intra-urbano, cada vez mais caótico em função dos conflitos de interesses entre o setor privado e a coletividade. $\mathrm{O}$ amadorismo da gestão municipal na cidade e no município, somado à força dos grupos econômicos historicamente vinculados aos ciclos econômicos e dos prósperos migrantes (vindos em busca das terras baratas e das riquezas da 
Amazônia), demonstra que a única saída para uma possível sustentabilidade seria a organização da sociedade em torno de temas como saneamento ambiental, migração e desenvolvimento sustentável, em um debate que deve extrapolar a cidade e o município de Marabá e novamente atingir a esfera federal, uma vez que as intervenções ocorridas na região sempre resultaram no reforço da desigualdade socioespacial e na exploração predatória do meio ambiente.

Marabá constituiu-se em uma cidade partida tanto socialmente quanto espacialmente, em conseqüência das experiências urbanísticas que resultaram em núcleos com configurações diferenciadas, em razão da origem do arruamento espontânea ou planejada - e da utilização do solo como componente de negociação entre os diferentes grupos sociais ali localizados. É possível encontrar na cidade variadas manifestações de separação socioespacial, com diferentes gradientes definidos em função da participação de agentes na produção do espaço urbano: a) resultado da iniciativa estatal ou da formação espontânea (Velha Marabá); b) confronto entre as idéias urbanísticas introduzidas pelo governo federal e as necessidades da população (como a cidade-castanheira com células que lembram o urbanismo modernista, mais pela fragmentação do tecido urbano que pela formação de unidades de vizinhança) (Nova Marabá); c) confronto entre a malha retangular e o traçado xadrez de escala com potencial mais humano e a desarticulação dos loteamentos de origem privada que se aglutinaram para formá-la (Cidade Nova). Outra característica da segregação é a maior ou menor permanência de migrantes no território. Eles podem estar concentrados dentro de uma folha da Nova Marabá, no entorno do bairro de condomínios e de propriedades muradas da Cidade Nova ou em meio à inundação na Velha Marabá, manifestação mais conspícua nas áreas de mistura de perfil populacional ou mais oculta nas periferias formadas ao redor dos bairros dotados de infra-estrutura e com maior valorização imobiliária.

\subsection{A Velha Marabá: a recorrência do clientelismo na cidade}

A segregação socioespacial na Velha Marabá é resultado de sua origem espontânea e das modificações sofridas em função das inundações regulares nos bairros ali localizados (Figura 10). Na Velha Marabá, como é conhecido o também chamado núcleo pioneiro, estão localizados o comércio varejista e a população tradicional. É também na Velha Marabá que as enchentes forçam, todos os anos, os moradores a mudar-se temporariamente para abrigos construídos pela Defesa Civil em local fora do alcance das águas dos rios Itacaiúnas e Tocantins. Os moradores, porém, dizem não querer ou não poder mudar-se devido às oportunidades de trabalho que encontram no local, melhores que as de outros pontos da cidade. As enchentes são enfrentadas com ajuda institucional e humanitária, o que consolida 
a dependência dos atingidos em relação às autoridades locais. Para as autoridades, a possibilidade de decretar "estado de emergência" é interessante porque agiliza o repasse de recursos, e para a população existe sempre a possibilidade de explorar lucrativamente as circunstâncias, como é o caso dos barqueiros que facilitam o transporte "fluvial" entre os pontos de chegada nas ruas não totalmente inundadas e as áreas que anteriormente serviam como ruas. Ano após ano o mesmo processo se repete.

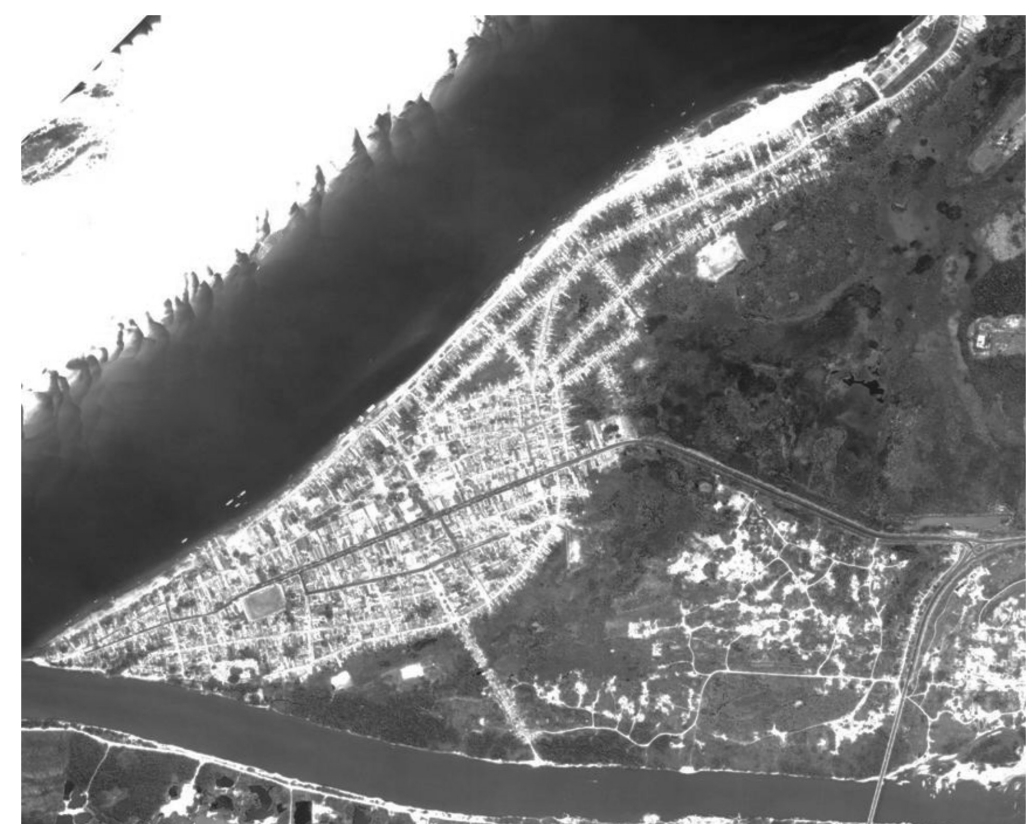

Figura 10: Imagem de satélite do Núcleo Velha Marabá.

Fonte: UFPA, PMM, 2006 a partir de INTERSAT, 2006.

A área mais vulnerável às enchentes é o pontal (desembocadura do rio Itacaiúnas no rio Tocantins), hoje ocupado pelo bairro Francisco Coelho, popularmente conhecido como Cabelo Seco (Figura 11). Nessa região as casas são geminadas, ocupam lotes intensivamente, não contam com banheiros nem paredes divisórias. As casas que fazem fundo com o rio utilizam-no como banheiro, como lavanderia e como espaço de lazer. Existem problemas de desmoronamento nas margens dos rios, o que motivou a construção de um cais, que já transformou a "beira" do Tocantins em "orla", e há previsão de que o mesmo ocorra na "beira" do Itacaiúnas (Figura 12). Tal intervenção, todavia, é setorial e não abrange a provisão de infra-estrutura de saneamento básico na área. Nesse sentido, foram feitas improvisações por ocasião da construção do aterro da orla do Tocantins, como as ligações diretas dos banheiros das casas com o rio, em prejuízo do saneamento ambiental e da proteção das águas do rio Tocantins, que abastece a cidade. 


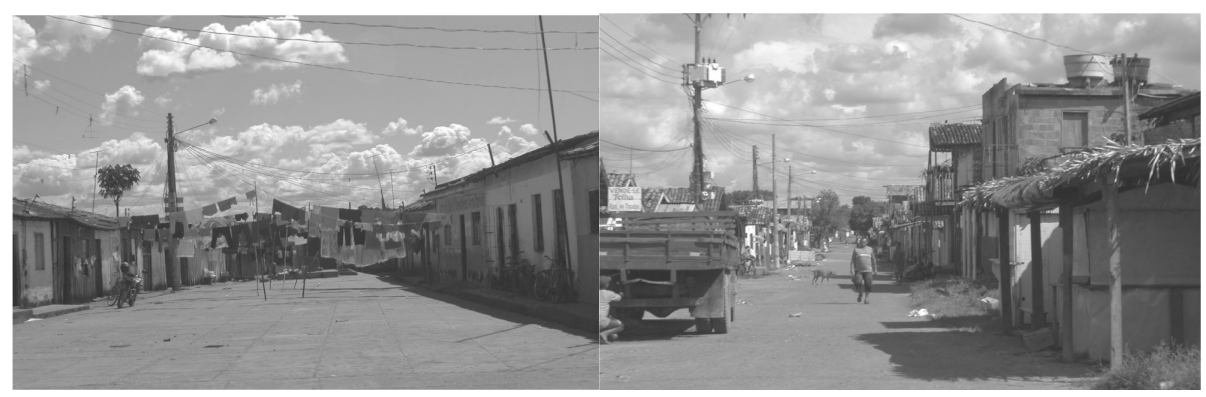

Figura 11: Bairro Francisco Coelho (Cabelo Seco).

Fonte: fotos de Ana Claudia Cardoso (2006).
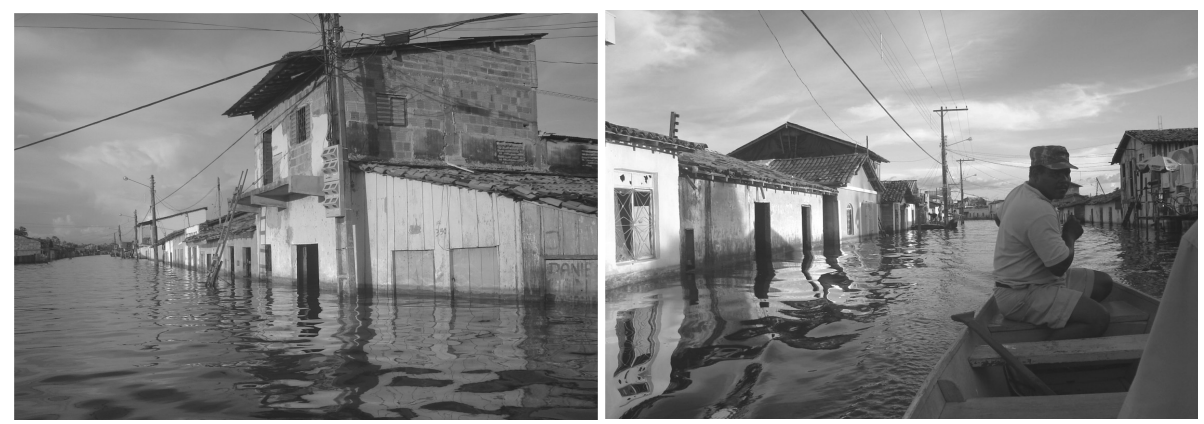

Figura 12: Aspectos de ruas da Velha Marabá alagada em 2006.

Fonte: fotos de José Júlio Lima (2006).

Atualmente a orla é uma área nobre, disputada por visitantes de toda a cidade, pela vista que oferece do rio - é possível observar o pôr do sol - e pela concentração de usos ligados ao entretenimento e ao lazer (casas noturnas) e de alternativas de alimentação (restaurantes, bares, lanchonetes). Tal diferencial teve como efeito colateral a concentração de casos de prostituição na área, a especulação imobiliária e a substituição da população original por segmentos sociais mais abastados (Figura 13).

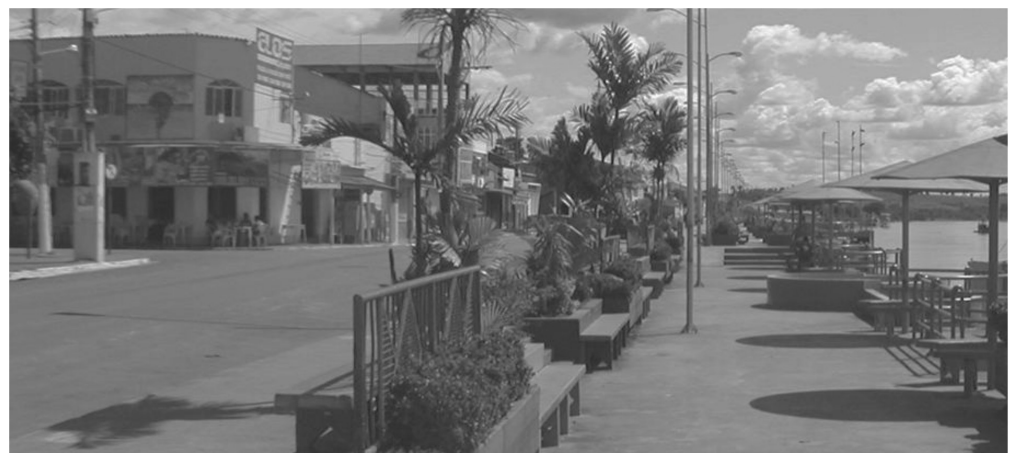

Figura 13: Aspectos da orla de Marabá após a conclusão das obras do novo calçadão.

Fonte: fotos de Ana Claudia Cardoso (2006). 
As carências de equipamentos (espaços de apoio à educação, à cultura, à saúde) na área decorreriam menos da escassez de espaço para a sua implantação do que da falta de vontade política de reciclar instalações existentes (como a antiga cadeia) ou de oferecer condições de funcionamento adequadas (escolas, creches). Há uma tendência para a substituição dos equipamentos existentes por outros voltados para o apoio ao turismo, em detrimento das necessidades da população.

A possibilidade de alocar investimentos públicos para a construção da orla ao longo do pontal revela a importância simbólica da área para a cidade, embora se mantenha submerso por até três meses todos os anos. Se a intervenção poderia significar melhoria da qualidade de vida da população original e a possibilidade de sua inserção na indústria do turismo, existem as pressões para que, uma vez preparada a orla, tal espaço possa ser explorado por edificações mais altas, que poderiam servir ao setor hoteleiro, que exploraria a paisagem única na cidade. Há incerteza quanto ao impacto das transformações sobre os preços dos imóveis populares e à sua conseqüente absorção pelo mercado imobiliário, em razão da desvantagem representada pela recorrente inundação na área. Não é certo, porém é provável que haja substituição de população porque a população de Marabá tem uma tradição de convívio com a inundação. A renovação de moradores deve ampliar o poder de barganha para que sejam continuadas as obras em direção ao pontal e finalmente executadas obras de melhoria sanitária visando eliminar os riscos advindos das inundações para o precário sistema de esgotamento sanitário e de coleta de lixo daquelas áreas. Seria mais proveitoso para a população tradicional se investimentos em saneamento passassem a compor a agenda política local tanto quanto as obras paisagísticas.

Na Velha Marabá, o comércio segue a tradição urbanística de concentração na rua principal, por onde passam mais pedestres dentro da malha quadriculada. A rua comercial localiza-se no centro do sistema e concentra os principais edifícios públicos e comerciais; a partir daí, ruas paralelas e perpendiculares fazem a transição entre o uso comercial e o residencial, normalmente com uso misto. A orla é um espaço que tende a especializar-se no apoio ao turismo. A praça central articula os usos formais e informais ao longo das calçadas. O comércio caracteriza-se pela complementaridade, com estabelecimentos de varejo especializado, principalmente de vestuário, farmácia, serviços e eletrodomésticos. A localização de escolas e instituições dá à Velha Marabá uma vitalidade que faz evocar o tempo em que ali estavam localizados depósitos de castanha, o tempo do movimento de subida e descida de embarcações no rio Tocantins antes da construção da UHE Tucuruí em 1984.

Observe-se que morar nos bairros Cabelo Seco, Santa Rosa e Santa Rita, 
além de ser barato, permite o acesso a pé ao centro comercial e aos equipamentos existentes no centro, assim como às atividades de pesca e de lazer na praia do Tucunaré (banco de areia localizado no rio Tocantins em frente à Marabá Pioneira). Por isso, a diversificação de fontes de renda é maior no centro do que em outros núcleos da cidade, aspecto muito importante para a população tradicional de baixa renda.

O casario é marcado pelas casas simples de porta e janela, com detalhes decorativos nas platibandas, embora existam residências mais cuidadas, de propriedade da antiga elite local. O pioneirismo da ocupação pode ser observado em ruas como a Cinco de Junho, que apresenta muitas casas preservadas desde as primeiras décadas da fundação da cidade e que constituem o seu núcleo histórico. A preservação dessa área pode ser valiosa para a construção de uma identidade para a população composta de tantos migrantes, que historicamente utilizaram a cidade como fonte de enriquecimento pessoal, sem desenvolverem ou fortalecerem relações afetivas com Marabá.

\subsection{A Nova Marabá: dificuldades para o projeto-desenho}

A busca de uma solução definitiva para o problema recorrente das cheias motivou o governo federal, por intermédio da SUDAM, a promover ações de planejamento urbano e a desenvolver um projeto urbanístico para Marabá, extrapolando as ações de infra-estrutura em curso na região. A SUDAM mandou realizar no início da década de 1970, estudos de viabilidade para a definição do melhor sítio para a expansão da cidade e para a implantação da Nova Marabá (GUEDES, 1072).

$\mathrm{Na}$ ocasião, descartou-se o assentamento localizado na margem oposta do rio Tocantins como possível alternativa (São Félix) e também o sítio localizado na margem oposta do Itacaiúnas. A grande quantidade de terras disponíveis na área escolhida levou à concepção de um projeto baseado no equacionamento da drenagem urbana por meio da utilização da declividade natural; a implantação

prevista evitou as áreas de varjões e manteve distanciamento das margens dos rios, contando com a rodovia Transamazônica como limite sul, com a rodovia PA-150 e a ferrovia Carajás como limite leste, com áreas militares e varjões como limite oeste, e a faixa de preservação da margem do rio Tocantins como limite norte (Figura 14). A concepção urbanística foi objeto de concurso, e a proposta selecionada foi alterada de modo a reforçar a hierarquização das ruas, pelo famoso sistema de folhas, constituído por uma malha ligeiramente deformada de avenidas de maior velocidade que modulam a cidade e contêm as unidades menores (folhas), onde as ruas acompanham declividades e geralmente recorrem ao cul-de-sac, ou 
beco sem saída, para limitar a interferência do tráfego nas moradias, em total conformidade com a concepção urbanística difundida pelo movimento moderno. Foi proposta uma ocupação extensiva do solo, que permitia a reserva de espaços não edificáveis suficientes para atuarem como "esponjas" de absorção das águas das chuvas, associadas a grotas e varjões existentes (Figura 15).

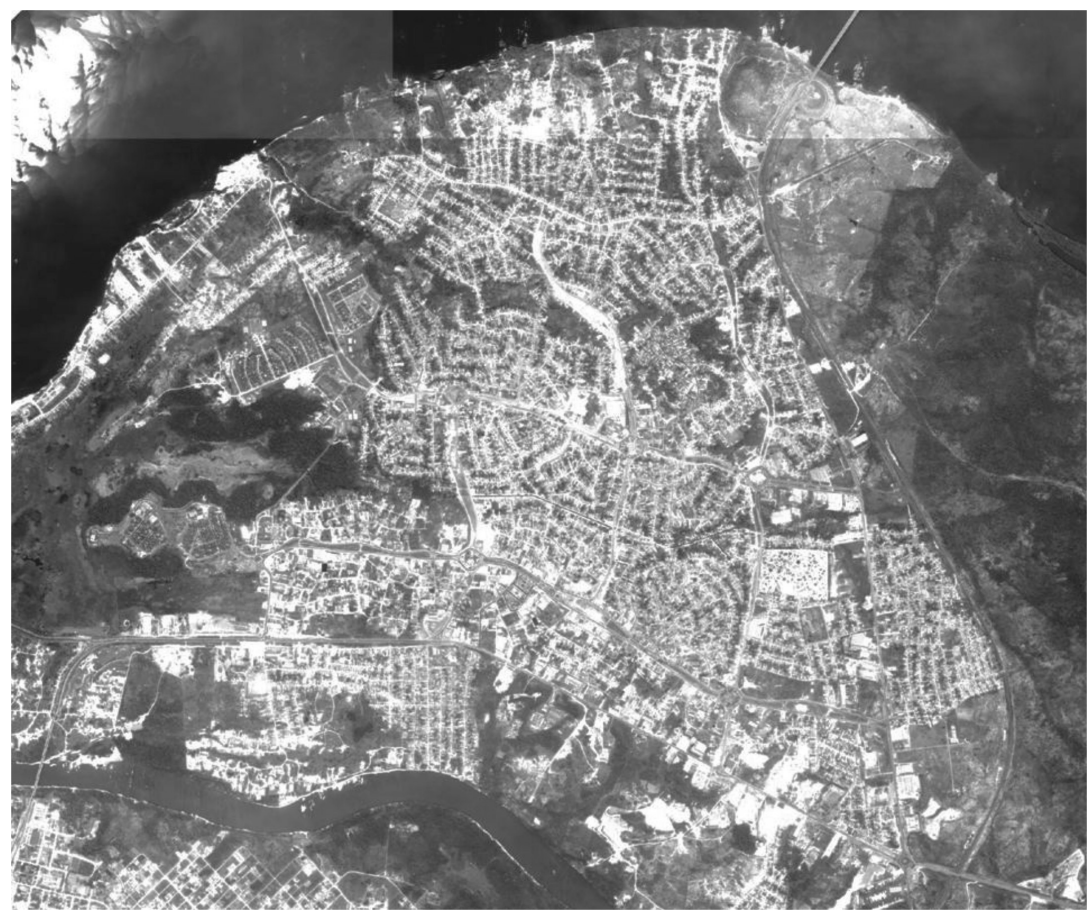

Figura 14: Imagem de satélite do Núcleo Nova Marabá.

Fonte: PMM, UFPA, 2006 a partir de INTERSAT, 2006.

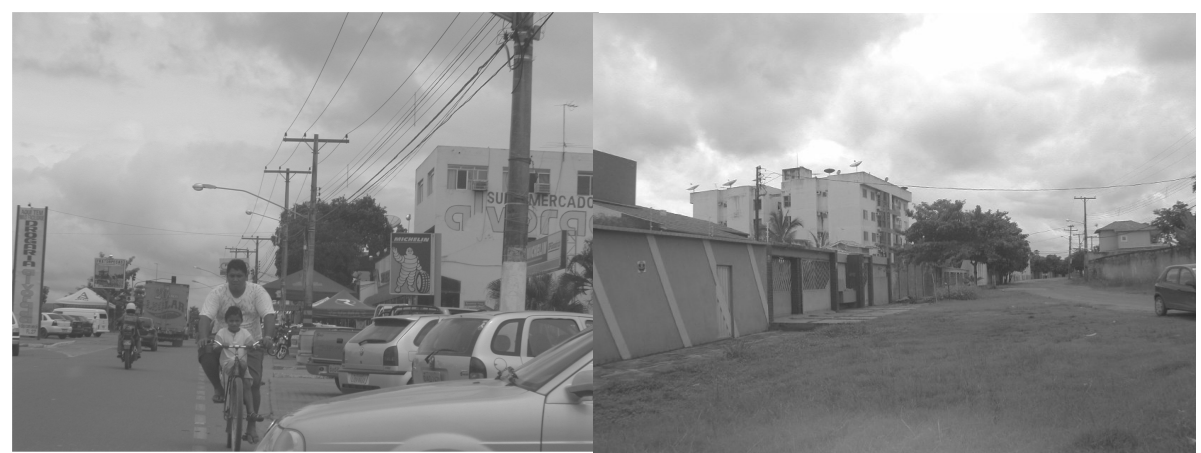

Figura 15: Avenida e interior de folha de alto padrão no Núcleo Nova Marabá. Fonte: fotos de Ana Claudia Cardoso (2006). 
Ocorre que, da mesma forma que o Governo Federal se retirou do cenário regional, a SUDAM abandonou o projeto de implantação da Nova Marabá. A área foi transferida para o município, assim como a incumbência de garantir a ocupação ordenada das folhas não implantadas. Entretanto, o desvirtuamento da proposta original deu-se tanto nas folhas que já teriam sido ocupadas por ocasião da transferência quanto nas folhas ocupadas posteriormente. Dadas as dificuldades de gerenciamento existentes, decorrentes das transformações que estavam em curso nos âmbitos político, econômico e social, o plano mostrou-se inútil, incapaz de aplicar os mecanismos de espacialização do capital na cidade ao espaço projetado, típico da concepção modernista. Os procedimentos de gestão tornou-o inócuo, para os fins a que se propunha.

O grau de segregação socioespacial percebido nas folhas da Nova Marabá demonstra o quanto a acessibilidade física, associada a dificuldades impostas pelo sítio físico à implantação de infra-estrutura, contribui para o aparecimento de segregação socioespacial no espaço urbano. Os eixos viários que integram as folhas permitem que os usos do solo nos lotes definidos em meio à profusão de rotatórias e vias locais sejam maiores que os da Velha Marabá. Para tais eixos, inegavelmente adequados às demandas da cidade-nó regional que se tornou Marabá, dirigiram-se os usos que demandam grandes lotes, como concessionárias, oficinas, depósitos e instituições; as folhas deveriam ter caráter mais residencial, mas os usos do solo e as condições de sua ocupação dependem da localização relativa da folha dentro da cidade.

A necessidade de criar instalações e moradias para a mão-de-obra dos poderes executivo e judiciário federal levou à implantação da infra-estrutura adequada nas primeiras quadras ocupadas, localizadas entre a rodovia Transamazônica e a grota Criminosa. Por falta de controle, porém, essa ocupação adensou-se demasiadamente, comprometendo a reserva de áreas para passeios públicos, duplicação de vias e zonas de rápido escoamento das águas. Essa área corresponde atualmente ao centro da Nova Marabá e abriga comércios e serviços, praças e usos institucionais, ao longo dos seus eixos principais. A disputa pela localização privilegiada ensejou a ocupação de toda sorte de áreas públicas e a construção de estabelecimentos comerciais até mesmo sobre adutoras de distribuição de água.

Outras quatro folhas localizadas entre a grota Criminosa e outro varjão nunca alcançaram o mesmo grau de distribuição de usos não residenciais e de provisão de infra-estrutura. As demais folhas já não seguiram o projeto, e foram evitadas algumas áreas - que, não por acaso, constituem a periferia social e espacial da Nova Marabá. As condições de acessibilidade são progressivamente limitadas no sentido norte, devido à falta de conexão entre as ruas das folhas, o que compromete o atendimento da população pelas duas únicas linhas de transporte coletivo da cidade. 


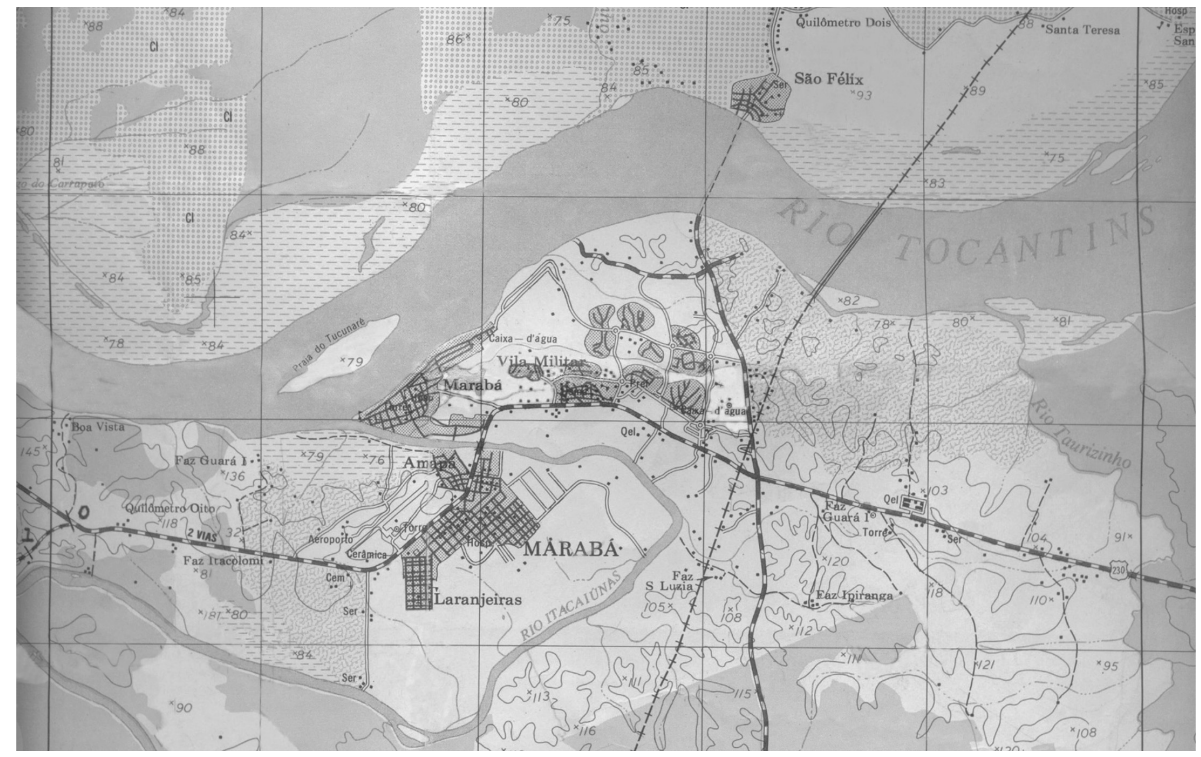

Figura 16 Ocupação dos núcleos na década de 1980.

Fonte: BRASIL, 1982.

A segregação é mais aparente nesse núcleo do que nos demais, uma vez que o parâmetro espacial adotado são folhas inteiras, e não porções periféricas do espaço urbano. Há folhas "melhores” e folhas "piores”, em função do sucesso na implantação da infra-estrutura viária e de saneamento. Haveria uma espécie de compensação entre as dificuldades impostas pela configuração do arruamento e as dificuldades impostas pela ondulação do sítio. As dificuldades de acessibilidade são as mesmas das cidades modernas, com limitação do número de conexões e de oportunidades para a socialização da população e conseqüente apropriação social dos espaços. Os elementos morfológicos lotes e ruas internas não são espacializados com a mesma qualidade que a quadra, o que causa dificuldades no endereçamento (as casas são identificadas pela associação do número da quadra, da rua interna e do lote). Além disso, os canteiros das rotatórias que articulam os grandes eixos são obstáculos para o pedestre.

A falta de correspondência entre as idéias "progressistas" do projeto da Nova Marabá e a cultura e a condição socioeconômica da população local fez com que esse núcleo fosse rejeitado como alternativa de localização para as áreas alagáveis da Marabá Pioneira, tanto para o uso habitacional quanto para o comércio e serviços. Os comerciantes locais mantêm uma filial em cada novo núcleo de Marabá e a matriz na Marabá Pioneira, convivendo com as enchentes até hoje. A proposta espacial da Nova Marabá foi mais bem aceita pelos grupos de migrantes (funcionários públicos, militares, etc.), que constituem a classe média 
urbana, e também pelos grupos mais prósperos, que dispuseram de mais área para construir suas moradias de luxo. Entretanto, paradoxalmente, as quadras mais bem cotadas em termos imobiliários são aquelas que apresentam maior percentual de terrenos não utilizados, enquanto as demais apresentam vegetação de quintais mais expressiva.

O eixo da rodovia PA-150 assumiu o comércio especializado em revenda e manutenção de veículos, além de postos de gasolina e suporte para atividades agropecuárias, que muitas vezes desprezam as condições naturais existentes. Assim, para ampliar o aproveitamento da margem da rodovia, constroem-se, sobre cursos d'água, aterros que, quando carregados pela força das águas na estação das cheias, colocam em risco a integridade da própria rodovia, apesar de sua importância para a cidade.

A ferrovia representa um obstáculo para a expansão da cidade na direção leste. Migrantes estão estabelecendo-se em assentamentos informais na outra margem da ferrovia, circulando sobre os trilhos para alcançar a cidade e colocando a própria vida em risco. A regularização da ocupação do outro lado dos trilhos depende da construção de pontes, como a ponte de acesso construída para atender necessidades da companhia estadual de saneamento - a Companhia de Saneamento do Pará (COSANPA) -, mas isso dependeria de parcerias com a Companhia Vale do Rio Doce, maior exploradora da ferrovia. Tais situações são claras manifestações do impacto dos grandes projetos desenvolvidos na região sobre o espaço intra-urbano de Marabá, no que se refere ao acelerado crescimento demográfico e às limitações de crescimento da cidade impostas pela infra-estrutura de apoio a esses projetos.

Atualmente a margem do rio Tocantins é ocupada pelas atividades de extração de minério (seixo) necessário para a produção do ferro-gusa, produzido nas siderurgias implantadas no distrito industrial da cidade. Diga-se de passagem que as matérias-primas mais consumidas na produção do ferro-gusa (um produto que compete com a sucata no mercado internacional) são o seixo e o carvão vegetal, fortemente associado ao desmatamento do município de Marabá e dos municípios vizinhos. O trabalho das dragas estende-se por toda a extensão do rio, causando no mínimo poluição sonora. A margem do Tocantins também abriga rampas para a travessia de balsas e pequenos portos. As obras de construção da orla resgataram o interesse pela preparação de uma via marginal ao rio Tocantins como alternativa de conexão da Marabá Pioneira com a Nova Marabá, uma vez que a única conexão existente aproveita o percurso da rodovia Transamazônica dentro da cidade, de onde parte um ramal de acesso para a Marabá Pioneira e o acesso à ponte sobre o rio Itacaiúnas, que conduz ao aeroporto e à Cidade Nova. 


\subsection{A Cidade Nova: especulação imobiliária}

A Cidade Nova desenvolveu-se a partir da ocupação rural existente na área, da presença da agrópole do INCRA, onde se localiza a sede da superintendência regional desse órgão federal, da instalação do aeroporto e da construção do conjunto Cidade Nova pela Companhia de Habitação do Estado do Pará (COHAB). Tudo isso está ligado à outra margem do rio Itacaiúnas pela ponte da rodovia Transamazônica (eixo articulador dos usos e assentamentos citados) (Figura 17). As terras onde hoje se desenvolve o núcleo Cidade Nova estiveram nas mãos de fazendeiros que promoveram loteamentos, que no seu traçado original avançaram sobre brejos e sobre a cota 80 . Alguns deles nunca foram completamente ocupados e mantêm-se como extensos vazios urbanos.

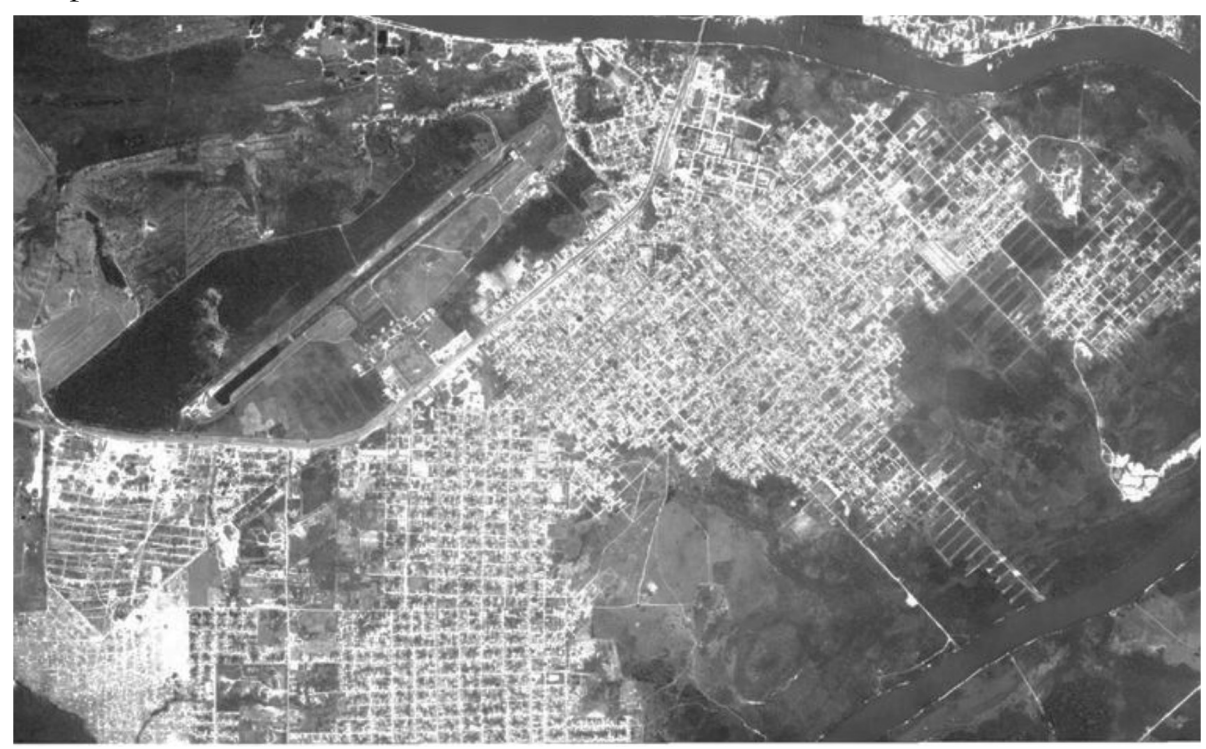

Figura 17: Imagem de satélite de parte do Núcleo Cidade Nova. Fonte: PMM, UFPA, 2006 a partir de INTERSAT, 2006.

Os loteamentos privados adjacentes às áreas preexistentes foram completamente integrados, o que ensejou a formação de uma cidade com diferentes centralidades, com um centro comercial especializado localizado ao longo da rodovia Transamazônica e outros centros de bairro localizados ao longo das ruas internas dos loteamentos (como nos bairros Laranjeira, Bom Planalto e Belo Horizonte). Nessas áreas observa-se uma concentração de residências amplas e de bom acabamento, apesar das deficiências ainda existentes quanto à provisão de infra-estrutura. Após essas áreas, nas quadras mais afastadas e menos infraestruturadas, vive a população mais pobre, também presente por trás do aeroporto. Nesses locais verificam-se os índices mais elevados de hanseníase da cidade, visto 
que, em áreas como o Amapá, a população convive com o transbordamento de fossas e a contaminação de poços. Nessa área também se concentravam usos industriais (serrarias) que já foram desativadas devido ao esgotamento da madeira na região. Restam os imóveis vazios correspondentes às instalações dessas serrarias, ainda controlados pelo setor privado, mais perto da rodovia Transamazônica que as áreas habitacionais populares. Houve uma iniciativa da prefeitura municipal para produzir uma habitação popular para além dessas propriedades, mas a área foi invadida antes da conclusão do projeto e hoje abriga o bairro Bela Vista.

O núcleo Cidade Nova diferencia-se bastante dos demais, por ser menos vulnerável à enchente que a Marabá Pioneira e por contar com uma organização espacial tradicional, bem diferente daquela existente na Nova Marabá. Entretanto, apresenta padrões de segregação de ricos e pobres em relação ao núcleo central muito claros, expressos na ocupação dos lotes, mais do que na diferenciação de espaços públicos (ruas, praças). É o núcleo que apresenta melhores possibilidades de expansão, apesar das restrições impostas pelo cone de proteção do aeroporto, visto que não existem obstáculos a oeste, na direção da Vila São José, mas as terras disponíveis são completamente controladas pelo setor privado.

A Cidade Nova é o núcleo de ocupação mais recente e de maior potencial para a segregação socioespacial devido à especulação imobiliária em curso e à formação de uma periferia urbana caracterizada pela combinação de precárias condições de infra-estrutura, de violência urbana e de acessibilidade limitada para os dois núcleos urbanos descritos anteriormente. Na Cidade Nova existem bairros que são objeto de especulação imobiliária, em função mais do status socioeconômico dos vizinhos (manifesto no tamanho e no padrão construtivo das casas) do que da infra-estrutura disponível, e que contabilizam o fator localização, com aumento de valor de troca sempre que novos investimentos imobiliários são implantados no núcleo.

\section{CONSIDERAÇÕES FINAIS}

Nas duas cidades aqui estudadas, constata-se que há limitações na articulação entre forma urbana e gestão. São claras as discrepâncias entre as estratégias de espaço e de localização da população adotada pelo governo federal e as políticas públicas associadas às intervenções estatais, e posteriormente entre aquelas estratégias e as transformações macroeconômicas e a reorganização políticoadministrativa do território brasileiro. Tem sido evidente a incapacidade do Estado para dotar a cidade de infra-estrutura e completar a transformação da terra rural em terra urbana, ou para acompanhar a passagem da base econômica de rural para rural e urbana, por meio de políticas públicas que ampliem e distribuam os benefícios da 
urbanização e permitam o enfrentamento das dificuldades decorrentes da origem das pessoas e das circunstâncias de sua instalação na cidade.

No caso do urbanismo rural aplicado ao entorno da rodovia Transamazônica, após algumas décadas, a proposta original de colonização mostrou-se completamente subvertida. Atualmente prevalece a falta de controle por parte do poder público, devido à falta de meios, à falta de recursos humanos e à falta de controle sobre a ação dos agentes responsáveis pela estruturação daquele território. A problemática ambiental posteriormente estabelecida na região, as dificuldades políticas e a busca do Eldorado pelos madeireiros são ingredientes novos, que suplantam em muito as possibilidades de produção dos colonos (sem água, sem estradas trafegáveis) assentados na região. Somem-se a isso as mudanças administrativas decorrentes de um novo pacto federativo entre União, estados e municípios, com transferência de responsabilidades quanto à condução de políticas públicas para o poder local, sem que muitos dos impactos causados pela atuação do governo federal (migração, introdução de novos atores, condição de acesso a terra, etc.) tivessem sido equacionados e sem que uma cultura urbana fosse formada para orientar a ocupação e a expansão da cidade.

Em Marabá, a discussão sobre a solução do problema das cheias sempre esteve defasada em relação ao ritmo de chegada dos fluxos migratórios. Enquanto se discutiam condições de abrigo ou remanejamento da população tradicional da Marabá Pioneira afetada pela cheia e outros núcleos eram criados, neles surgiram outras áreas suscetíveis de alagamento (abaixo da cota 80). Agrava-se assim o impacto das cheias a cada ano, como conseqüência direta das limitações da gestão municipal. Marabá apresenta problemas de cidades médias, mas conta com uma gestão ainda baseada na dependência de segmentos sociais em relação a outros, por causa das antigas práticas de aviamento; o amadorismo e os interesses políticos prevalecem sobre as estratégias de desenvolvimento urbano e o compromisso de reduzir as desigualdades locais. As elites dominantes, detentoras de terras e financiadoras das campanhas de autoridades eleitas, reclamam favores e privilégios que representam um retrocesso em relação à política urbana proposta a partir da Constituição Federal de 1988. Agentes como a Companhia Vale do Rio Doce não são chamados à mesa de negociações com a sociedade da cidade, a fim de buscarem soluções para as limitações impostas pela infra-estrutura implantada para seus projetos.

As atividades com potencial de geração de receita para o município, desenvolvidas na clandestinidade e de forma predatória (exploração de madeira e de gemas), não causam impactos na receita municipal, o que limita a ação da prefeitura na cidade e no campo. As condições de infra-estrutura e a falta de capacitação 
comprometem a produção em assentamentos da reforma agrária localizados no restante do território municipal. Além disso, os migrantes vindos do Nordeste do país dificultam o desenvolvimento de uma cultura urbana no município, uma vez que, como todos os assentados, consideram que as condições disponíveis nas piores periferias nos três núcleos da cidade ainda são melhores que as condições anteriores em que viviam.

A observação das duas cidades permite constatar que as cidades pequenas estão tão partidas quanto as cidades médias ou as metrópoles e apresentam-se divididas física e socialmente. Os habitantes pobres de Medicilândia dependem das oportunidades de trabalho criadas pelas serrarias e pelas fazendas e experimentam grandes restrições à capacitação e ao acesso a melhores oportunidades de trabalho. As dificuldades historicamente enfrentadas suscitaram uma forte articulação dos movimentos sociais da região em torno das causas rurais, mas a apropriação por tais movimentos das contradições intra-urbanas ainda está em construção. Desse modo, a cidade ainda seria um lugar onde vale tudo, onde a construção de regras em benefício do interesse coletivo parece um objetivo distante de ser alcançado, onde a importância do domínio público e da própria essência da urbanidade e da civilidade ainda está por ser compreendida por comerciantes, loteadores e habitantes em geral.

Em ambas as cidades, predomina a atitude especulativa com relação à utilização do solo por parte da população de melhor poder aquisitivo, o que resulta na ocorrência de vazios urbanos e na substituição da edificação existente por outras que reproduzem mais intensamente o solo e, dessa forma, permitem uma exploração econômica da localização em questão. Outra manifestação de descaso com relação às regras sociais é a ocupação indevida de espaços públicos, particularmente intensa na Nova Marabá (canteiros de avenidas, áreas verdes e afastamentos) e na periferia de Medicilândia (ruas).

\section{REFERÊNCIAS}

BECKER, Bertha; NASCIMENTO, José Antonio Sena do; COUTO, Rosa Carmina de Sena. Padrões de desenvolvimento, hidrelétricas e reordenação do território da Amazônia. In: MAGALHÃES, Sonia; BRITTO, Rosyan; CASTRO, Edna (Org.). Energia na Amazônia. Belém: Museu Emilio Goeldi; UFPA; Associação de Universidades Amazônicas, 1996. p. 787-815.

BRASIL. Ministério do Exército. Departamento de Engenharia e Comunicações; Diretoria de Serviço Geográfico. Região Norte do Brasil. Rio de Janeiro, 1982. Mapas. Esc. 1:> 100.000. folha MI-872. 
CAMARGO, José Geraldo da Cunha. Urbanismo rural. Brasília, DF: Gráfica Gutemberg, 1973.

CARDOSO, Ana C. D. et al. O espaço produzido informalmente como recurso para superação da pobreza urbana. Relatório de pesquisa CNPq. Belém: DAU; UFPA, 2006.

COMPANHIA DE HABITAÇÃO DO ESTADO DO PARÁ. Levantamento Aerofotogramétrico de Marabá. CD. Belém. 1998.

FUNDAÇÃO VIVER PRODUZIR E PRESERVAR; DEPARTAMENTO DE ARQUITETURA E URBANISMO. Diagnóstico dos municípios de Placas, Medicilândia e Pacajá. Belém, 2005.

GUEDES, Joaquim. Plano de desenvolvimento urbano de Marabá: Nova Marabá. Marabá, 1973.

MAGALHÃES, Sonia; BRITTO, Rosyan; CASTRO, Edna (Org.). Energia na Amazônia. Belém: Museu Emilio Goeldi; UFPA; Associação de Universidades Amazônicas, 1996.

MCCLUSKEY, Jim. El diseño de vías urbanas. Tradução de Road Form and Townscape. Barcelona: Gustavo Gili, 1985.

MORRIS, A. E. J. History of Urban Form: before the Industrial Revolution. 3. ed. Londres: Longman, 1994.

ORGANIZAÇÃO DAS NAÇÕES UNIDAS. Relatório de Avaliação de Vulnerabilidade Ambiental Marabá. Coordenado por Raiol, José de Andrade. Disponível em www.onuhabitat.org. 2006.

SUPERINTENDÊNCIA DE DESENVOLVIMENTO DA AMAZÔNIA. Plano de expansão urbana de Marabá. Belém, 1977.

TOURINHO, Helena Lúcia Zagury. Planejamento urbano em área de fronteira econômica: o caso de Marabá. 1991. Dissertação (Mestrado em Desenvolvimento Sustentável) - Núcleo de Altos Estudos Amazônicos, Universidade Federal do Pará, Belém, 1991. 2 v.

UNIVERSIDADE FEDERAL DO PARÁ; PREFEITURA MUNICIPAL DE MARABÀ. Diagnóstico do Plano Diretor Participativo de Marabá. Não publicado, 2006. 
VELHO, Otávio Guilherme. Frentes de expansão e estrutura agrária: estudo do processo de penetração numa área da Transamazônica. Rio de Janeiro: Zahar Editores, 1972.

WEBER, Max. Conceito e categorias da cidade. In. VELHO, Otávio Guilherme (Org.). O fenômeno urbano. Rio de Janeiro: Zahar, 1973. p. 68-89. Publicado originalmente em 1921.

YOSHIOKA, Reimei. Avaliação de implantação de núcleo urbano na Amazônia: exemplo de Nova Marabá-Pará. 1986. Dissertação (Mestrado em Geografia) - Universidade de São Paulo, São Paulo, 1986. 